Marcin Stawiarski

Université de Caen Normandie, France
2016, Vol. 13 (1), 69-79(167)

revije.ff.uni-lj.si/elope

doi: 10.4312/elope.13.1.69-79

UDC: 821.111(73).09-31McCourt J.:78

\title{
Eccentric Voices and the Representation of Vocal Virtuosity in Fiction: James McCourt's Mawrdew Czgowchwz
}

\begin{abstract}
This paper examines the representation of vocal virtuosity in fiction. It focuses on the concept of voice as it is represented in a work of fiction through musical eccentricity. The paper centres on James McCourt's Mawrdew Czgowchwz (1975). James McCourt's novel tells the story of an opera singer, Mawrdew Czgowchwz. In the novel, the voice is related to extravagance and fanaticism, so that it relates to violence and conflict. In McCourt's novel, the stylistic features of the text show a hyperbolic use of language resorting to Rabelaisian lists, foreign vocabulary, neologisms, or nonce-words, which create tongue-twister cornucopia effects of linguistic musicality. The paper aims to demonstrate that (a) the mode of eccentricity is a fundamental mode of representing music in literature; (b) eccentricity rubs off on the very structure of the text, so that it leads to singular forms of operatic musicalization of fiction and musicalized writing; (c) the voice ends up turning into a fetish object.
\end{abstract}

Keywords: fiction; music; voice; eccentricity; musicalization of fiction

\section{Ekscentrični glasovi in predstavitev vokalne virtuoznosti $v$ romanu Jamesa McCourta Mawrdew Czgowchwz}

\section{POVZETEK}

Avtor analizira načine predstavitve vokalne virtuoznosti v leposlovju, pri čemer se osredinja na koncept glasu, ki se v leposlovnem delu kaže z glasbeno ekscentričnostjo. Gre za roman Jamesa McCourta Mawrdew Czgowchwz (1975), ki pripoveduje zgodbo o operni pevki Mawrdew Czgowchwz. Glas v romanu je ekstravaganten in fanatičen ter vzbuja asociacije na nasilje in konflikte. Za McCourtov slog je značilna hiperbolična raba jezika, polna naštevanj v stilu Rabelaisa, tujk, neologizmov in nesmiselnih besed, ki zaradi težke izgovorljivosti prispevajo $\mathrm{k}$ muzikaličnoti jezika. Namen članka je prikazati (a) ekscentričnost kot osnovni način predstavljanja glasbe v književnosti, (b) vpliv ekscentričnosti na samo zgradbo besedila, ki vodi v specifične oblike poglasbenja leposlovja in (c) glas, ki se na koncu spremeni v fetiš.

Ključne besede: leposlovje; glasba; glas; ekscentričnost; poglasbenje leposlovja 


\section{Eccentric Voices and the Representation of Vocal Virtuosity in Fiction: James McCourt's Mawrdew Czgowchwz}

\section{Introduction}

"She's a STAR!" (McCourt 1975, 99), says one of the characters in James McCourt's novel Mawrdew Czgowchwz, published in 1975. The novel deals with the rising to fame of the eponymous operatic singer. Czgowchwz is an extraordinary diva modeled on various historical opera figures, such as Maria Callas or Victoria de Los Angeles. However, obviously, Mawrdew is a purely fictional construct, and a heterogeneous one at it. Indeed, her very name is bedecked with multiple semantic echoes: while her first name hints at the Irish exclamation mar dhea, which expresses disbelief, her family name phonetically conveys magnificence and graphically alludes to the vocal intricacies of diagraphs and unpronounceable consonant clusters in Slavic languages. ${ }^{1}$ Czgowchwz is a composite vocal creature: American, Irish, Czech or Polish, she commands disbelief, beggars description and stupefies by her vocal peculiarities.

The novel traces the story of a singer who is put on a pedestal and transformed into a living legend. By displaying the excesses of the voice, the book focuses on questions of identity and engages with the ins and outs of myth-fraught celebrity. Since the novel underlines the primacy of the voice-object ${ }^{2}$, I wish to contend that it establishes an analogy between voice, devotion and eroticism. Eccentricity has a crucial bearing on my argument since all these notions have something to do with excess - they all overflow, go beyond mere subjectivity, and elude us by transgressing socially imposed limits.

I shall first focus on the figure of the diva and her devotees by interrogating the notion of eccentricity. Second, I shall concentrate on the text itself and the idea of stylistic excesses. Finally, I shall underline the role played by the voice-object as an erotic force.

\section{The 'Oltrano' - A Diva Par Excellence}

Czgowchwz embodies the advent of a new vocal era at the New York Metropolitan Opera. Her unique novelty is related to the emergence of a new type of voice: the oltrano. It is Mawrdew herself who coins the new vocal category that covers the span from "falcon contralto" to "soprano d'agilità". What the term oltrano betokens is, first and foremost, the idea of alterity. The Latin root "alter", meaning the other, connotes otherness. The voice is always the other voice, unknown and unheard of: "Miss Czgowchwz currently claims a working range of three and a half octaves, from $\mathrm{C}$ below middle $\mathrm{C}$ to $\mathrm{F}$ sharp in alt, and frankly admits to having three register breaks and four "voices"” (McCourt 1975, 6).

Celebrated for the outstanding character of her voice, Czgowchwz is literally enthroned: one possible anagram of oltrano may be found in Italian al trono, and since the Latin "alter" can be related to both Latin altar (altar) and altus (high) the diva is deified and carried in a throne: "Miss

Polish has many diagraphs - cz, sh, rz, dz, dż, dź - which convey the impression of a complicated unpronounceable sounds. Other letters that are not diagraphs relate to similar consonants: Polish ś, ć, ż, ź, or Czech č or š.

2 For further background to this concept see Wesling and Sławek (1995), Dolar (2006), Le Breton (2011), and Sacido-Romero and Mieszkowski (2015). 
Czgowchwz is to be carried from the Plaza to the opera house at noon today in an elaborate sedan chair especially constructed for the occasion [...]" (McCourt 1975, 7).

Czgowchwz rises to public notoriety so suddenly that her fame brings about a true revolution. The world seems to have drifted into a wholly new phase. Time is of the essence as the book tells us the story of that precise moment - the years of the diva's blossoming career. But we are also told about the end of another diva's career. The opera singer Morgana Neri is about to be dethroned by her rival Czgowchwz:

There was a time (time out of mind) in the sempiternal progress of the divadienst, at that suspensory pause in its career just prior to the advent of what was to be known as "Mawrdolatry," when the cult of Morgana Neri flourished in the hothouse ambiance of the Crossroads Café [...] (McCourt 1975, 3).

From the very start, the question of the voice is garnered in a complex network of time-related images: while the idolatrous service to the diva - the dienst - is clearly described as everlasting, the voice itself is that which is subject to change, evolution, and ageing. The voice is temporal and only temporary, and, like fame, it is bound to atrophy.

Hence, the book deals with the voice by confronting multiple time constructs: the sempiternal progress of devotion contrasts with the limited and directed time arrow - the teleology of that particular voice and that particular period of notoriety, whereas the pattern of cycle is intimated with a series of successions.

The voice is exposed through time, because opera-going and opera-adulation have something to do with temporal peculiarities. While the temporality of impersonation evinces something immaterial and a-temporal - it is a time out of mind - the historical time "may be said to waste and to lose and to kill" (McCourt 1975, 4). What the novel explores is precisely that specificity of a moment when "It ended. Time told on Neri, whence the Neriad took a turn for the tragic [...] Mawrdew Czgowchwz became the diva of the moment and the moment went on" (McCourt 1975, 4). And the tragic chronos is inherently tied up with the tension between the illusion of sempiternality that worship and idolatry convey and the illusion of the bare merciless, historical progression: "The history took over for a time, cruelly, efficiently, with few stylish flourishes" (McCourt 1975, 10).

However, the plot of the novel focuses not only on the story of the new diva but also on the clan of her admirers. The main theme of the book is actually less about the centre - the diva herself - than about the periphery occupied by her devotees. In fact, the notion of eccentricity may be understood in relation to that of centrality: the eccentric occupies an out-of-centre locus, in contrast to the in-of-centre space of the in-centric. This spatial tension is heightened within the novel, where the out-of-centre initiates gather within their own hermetic circles while the diva, though central, is constantly directed elsewhere. The term oltrano can be correlated with Italian oltre, meaning "beyond". Little happens in the text itself apart from shows, fetes and adoration parties, which offer us a fictional insight into an intimate circle of New York opera-lovers.

The tension between the centre and the periphery being thus exposed, the cult of the voice is made to stand for a fanatic, quasi-religious and ritualistic adulation. When referring to the previous diva, the text emphasizes the spiritual and ritualistic nature of cult:

Neri was considered ageless, her voice deemed eternal. The elders, who could actually speak of the Neri debut, were revered by initiates as prior saints. Wire recordings of Neri 
broadcast performances passed like transcripts of the Orphic mysteries from fool to fool. (McCourt 1975, 3)

Hence, the cult of the diva smacks of religious fanaticism. The advent of Czgowchwz is said to lead to the audience's "conversion" (McCourt 1975, 20) and the commitment to the diva turns into a zealous adoration by a small group of opera freaks or disciples - like Ralph who "was and remains the truest of devotees, keeping a recorder plugged into a radio receiver day and night, day in, day out" (McCourt 1975, 8).

The voice-object becomes even freighted with messianic overtones, suggesting a sacred voice, implying both a hidden message and a sacred "salvific" mission. The group of devotees, called the Secret Seven, displays aspects of religiosity. The secret society believe in a mission to be carried out by the otherworldly voice, capable of passing down some 'hidden truth'. The voice becomes a metonymic part of the venerated whole - the symbolic relic to be revered.

Worship turns into a work of collective admiration and memory. Within the collective temporality, there emerges a collective, metaphoric voice of the crowd. It is "the collective mind recalling Czgowchwz" (McCourt 1975, 25). But, then, the act of recalling of Czgowchwz occurs as if by anticipation and foreshadowing, so that the devotees' activities consist in mindfully turning the present into an immediately recallable and memorable past, as though it were a work of pre-reminiscence - living the present by projecting it into a future past.

Frantic devotion, "universal ecstasy" (McCourt 1975, 21), and eccentricity belong to the brink of the centre: they share this common etymology of being out of phase with the centre. That outof-centeredness is based on the transformation of the present and the blurring of the boundaries between art and life: "Art and life were fused" (McCourt 1975, 22). The eccentric diva leads her devotees beyond the centre - she decentres them by throwing them into a permanent state of ecstasy, a state of hysteric adulation and frenzy, whereby her fans crawl along pavements, organize hunger strikes to pay tribute to their goddess, keep track of all the press events bearing on the diva, launch a special radio station dedicated to her (WCZG-FM), and record her performances with "tape recorders hidden under seats" (McCourt 1975, 96).

Eccentric glorification of the voice is obviously not devoid of humour and parody, which constitute de-centering factors. Paradoxically, the elitist nature of opera is at once highlighted and kept at bay, as it is disseminated into the popular culture of the carnivalesque and the masquarade. A summer edition of Paris-Match (McCourt 1975, 73) is devoted to Czgowchwz. Finding a serious opera article published in Paris-Match is hardly imaginable. Therefore, the eccentric popularity is brought to a limit, beyond which it turns into grotesque caricature and burlesque parody. ${ }^{3}$

\section{Text as Opera or Narrative Eccentricities}

Some of the events in the novel take place during "the opulent season" (McCourt 1975, 60) of the Yuletide. Characters are depicted as sybarites, addicted to luxury and hedonism. And the text lends itself to such an aesthetic of opulence and luxury. Something seems to rub off from the eccentric voice onto the textual poetics itself. As if to mime the oltrano lavishness, the language of the narrative produces an effect of excess by making use of various hyperbolic devices to create an almost fabulous opera effect.

See my article on musical eccentricity: Stawiarski (2015a). 
The specificity of the hyperbole lies in the effects of language. Just like the voice which abides by the principle of a cornucopian abundance, the text gives us a feeling of verbal exhaustion: the concentration of assonances and alliterations, parallelisms and paronomasia, similar wordendings, and macaronic use of words, especially Gallicisms such as "blancmange", "entrechats", "mannequins" "beige boudoir" "protégée" (McCourt 1975, 34-35). The reader might be tripped up by those words, grappling with language. If the text were to be performed, it would require a pretty fair command of language and high vocal skills, as some passages act as tongue-twisters. There seems to be a barroco $0^{4}$ effect of verbal preciosity and musicality, predicated on irregular mannerism.

Such saturated use of language is thematically underlined by another characteristic feature of McCourt's narrative which is its frequent punning on the very idea of musicality, ${ }^{5}$ i.e. the relationship established between 'reality' and music. Sound and voice undergo a musical treatment, often in jest, whereby language is compared to music, as if the text suggested a specific sound quality, that of a recitative, for instance, or as if it intimated a vocal opera effect as in the following examples: "opening the box in tremolo" (McCourt 1975, 12), "her sotto voce reservations" (McCourt 1975, 52), "Czgowchwz spoke equivocally, in E minor" (McCourt 1975, 56), "sentiments to these, voiced in polyphonic consensus" (McCourt 1975, 67), "antiCzgowczwz cant rattling on sforzato" (McCourt 1975, 100).

The novel resorts to a metaphorically musicalized description of reality ${ }^{6}$ - "snow whirling 'a silent, incessant concerto" (McCourt 1975, 34) - which not only keeps reminding us of its musical background, but it also creates a hyperbolic effect of humorous inapplicability. Furthermore, such metaphorical depictions are frequently accompanied by pictorial renditions of sound, the template of which is to be sought in the device of hypotyposis, that is to say a vivid description by which sound is reified: "He laughed - a laugh, they said, like treacle bursting from barrels - misting the surface of the perfect globe. [...] (Chuckling, treacle turned to tar)" (McCourt 1975, 36).

Hypotyposis itself is a form of hyperbole especially when it extends the domain of langue to other media, or leads to absurd and grotesque effects. The exaggeratedly pictorial and tangible representation of sound evinces almost inevitably a comic clash between sources and media. The grottesco tallies perfectly well with the idea of precious ornamentation and caricature that blows the original out of proportion. Since the voice is a distorted and 'unnatural' sound, it goes hand in hand with the grotesque, satire and caricature which the language of the narrative brings to the fore.

Hypotyposis is further extended within renderings of performances or musical ekphrasis, ${ }^{7}$ as in the following example:

The 'Sempre libera' began; it built. The voice grew; the sides of it fell off, the bottom opened (like the portals of doom), and Czgowchwz soared in flames to B naturals fullvoice. There were in voluntary screams, shock upon shock, fresh denials from every tier, but Czgowchwz sped forza allegretto, waltzing in circles until there was to be seen but a single swirl of jet lace pinwheeling in dervish abandon. [...] The final measures were upon her; the optional E flat hung fire. She rose higher and wider by turns. The voice seared, shooting out of the whirling smoke of her consumptive waltz. [...] For an instant there

The word barroco originally stood for an "irregular pearl".

For further information on musico-literary relations, see Brown (1987), Scher (1982), and Cupers and Weisstein (2000).

See my paper on musical metaphors in literature: Stawiarski (2015b).

For the concept of ekphrasis and text/image relations, see Louvel (2011). 
was no sound; then something unheard since the creation - a Czgowchwz fortissimo A natural above high $\mathrm{C}$ the color of the core of the sun (McCourt 1975, 20).

There is a contiguity between opera and reality, life, and the world. Reality is shown to imitate operatic artifices and it can be read through an imaginary opera prism. The device of the objective correlative offers one example of such contiguity: "Outside everywhere the snow went on hurtling down at the same dizzying velocity (precisely) at which the notes rose, concomitant as well in density - relentlessly metaphoric [...]" (McCourt 1975, 41). Another example is provided by the idea of quasi-literal correspondence between life and opera - the notion of paralleling or reading oneself through opera. ${ }^{8}$ The characters themselves are shown to indulge in such paralleling by reading opera into their diva: "Dolores ran an entire column paralleling her reading of the story of Mélisande with her understanding of the true story of Mawrdew Czgowchwz" (McCourt 1975, 153).

Another form of hyperbolic saturation which brings opulence into focus is the use of Rabelaisian lists and the pattern of the line. The novel frequently resorts to lists with its concatenations of words, endings and even blocks of sentences as in this series of parentheses - "(the year before the war) (the year she won the Irish Sweepstakes) (the first year...)" (McCourt 1975, 24). Within the pattern of the list, we also find the crucial notion of paradigm. And the logic of the paradigm is not only the rationale behind the stylistic features of the text. It also mirrors the vocal eccentricity itself. Since the paradigm is the type example of all possible variations a type can espouse, the enigmatic voice of the diva may be conceived itself as a vocal paradigm, insofar as it bears the potential of any voice. The excessive vocal singularity translates into the all-encompassing mechanism of the paradigmatic.

Furthermore, intermedial metaphors also contribute to the hyperbolic effect. The novel refers to some "special effects [that] were being conceived" (McCourt 1975, 26). One could even consider special effects as a metaphor for the opera, the voice and the narrative. Prominent features and the aesthetic of saturated verbal devices can be viewed in this way; and so can the very notion of intermediality. The narrative refers to interrelations between different media through vocal hybridity. There is a form of generic multiplicity in the text, with references to numerous sources, among which one finds quotes from recorded voices, ${ }^{9}$ but also specific genres such as the journalese and a hodgepodge of press releases which record the diva's public appearances. The continuation of Mawrdew Czgowchwz, Now Voyagers is even more clearly a form of vocal mélange, presenting itself as a multiple person narrative, with intermingling quotes and epistolary fragments.

On account of its intermedial hybridity, one might argue that the novel is an attempt at a transposition of an aesthetic of opera into fiction, a case of operatic musicalization of fiction. ${ }^{10}$ As such, just as the unnatural voice and the artifice of the opera lie at the heart of the novel, so too does the text seem to be a sort of 'unnatural' narration, emphasizing the irreducible of the voice which proves impossible to pin down:

The Wonderous saga of the second Czgowchwz return, in the psychic pannage season, that return from regions all too few have ever charted, is many sagas' interweaving. The vast unraveled display of all versions, points of view, convictions, and testimonies of so

On interrelations of opera see, for example, Halliwell (2005) and Bernhart (2006).

Some of the voices are said to have been recorded, when, for instance, a character is shown "to record his continual amazements into a small portable Dictaphone" (McCourt 1975, 100). The reader is given scraps of such voice-traces: quotes acting as transcription of such recordings.

10 For the concept of 'musicalization of fiction', see Wolf (1999). 
many compulsive seekers after Czgowchwz truth suggests the spectacle of some tickertape parade's litter-choked aftermath, supposing the triumphant Czgowchwz comeback's wake papered with incessant strips of pertinent leading-clue material: depositions, letters, reports, ad hoc, ad lib, ad nauseam, ad infinitum... (But no sentence in fact or fiction could convey the discrete truth, or for a certain fact get nearer to that shifting mystery than any words get to the true fulfillment of that unique resolve the Shadow in the recess of the mind resolves) (McCourt 1975, 111).

What this hyperbole expresses is the elusive character of excess: the singularity of music, voice and devotion provide "far too much to tell" (McCourt 1975, 164) and "beggar[ed] description" (McCourt 1975, 161).

\section{Voice-Fetish}

The elusive effect of vocal excess is conducive to a dream-like, rite-like trance. On the cusp of the vocal and the verbal, the voice has an impelling aspect which has something to do with eroticism and subordination, erotic submission and collective frenzy. Czgowchwz's fans are depicted as being in "a state of belonging (to Czgowchwz)" (McCourt 1975, 25), as though one belonged to another's voice. "True stars impel" (McCourt 1975, 24), states the text, suggesting the notion of vocal force or even vocal violence. Such force is linked to the verbal power able to "bewitch [her] listeners, dispelling anguish like grace, inducing sweet narcosis to cure life of complication and dolor" (McCourt 1975, 131). There is a violence to the diva's vocality.

Czgowchwz's voice crosses all barriers: "The Czgowchwz voice had carried well beyond the visible walls" (McCourt 1975, 93). The oltrano is not merely una altra voce, but una voce oltre, beyond centrality and beyond common locus. The oltrano is an unusual, unearthly voice: "The 'Dite alla giovane' seemed to come from a voice within the voice; the 'Amami, Alfredo,' from a voice without" (McCourt 1975, 21). It is at once a super-voice, a paradigm of all voices, and a hypertrophied self or a hyper-voice. ${ }^{11}$ The diva's performance becomes unbearable, as if the listening to the oltrano's fiery voice were like the contemplating of a medusa: "Many in the audience turned sharply away as from the accusing sun" (McCourt 1975, 97). When Czgowchwz sings Liebestod, she becomes "a voice beyond voices (the oltrano) was singing a passage beyond passage" (McCourt 1975, 105). When singing Mélisande, Czgowchwz resorts to an even more unearthly voice register: "She would use the 'fourth voice' Calvé spoke of once" (McCourt 1975, 149). This is a reference to Emma Calvé and what she used to call her "fourth voice,"12 a strange uncanny, high-pitched whistle register. ${ }^{13}$

But Czgowchwz's voice is not the only vocality represented in the text ${ }^{14}$. The diva's relationship

The singularity of the oltrano voice appears in the uniqueness of the performance - the diva sings as if she were to perform once and for all, as if the performance were the ineluctable necessity that was bound to happen. When she sings four Mahler songs, "the act itself was subsumed in a longing moment that seemed to have been absolutely destined to occur, to be accomplished only and for all time then and there in merely that way" (McCourt 1975, 62). There is no possibility of voice after Czgowchwz - by singing she annihilates the voice. Yet, when she sings "the most potent, magical-archetypal SHE in all opera” (McCourt 1975, 72), singing Isolde in Irish "as if possessed" (McCourt 1975, 104), she incarnates all voices.

12 Called "whistle register" by Berton Coffin - see, Coffin's sounds of singing.

13 This unnatural otherworldly voice commands eccentric music composed by Creplaczx: "This music topped the most diabolic demands yet made in the twentieth century, even those made by the mad Hollenius. It was too impossible. Yet he must, he knew, sing it. [...] it contained wild leaps, melismatic arabesques, occasional requirements for singing off pitch, and rhythmic aberrations verging on deliberate travesty" (McCourt 1975, 177).

14 There are vocal tensions and oppositions, such as the one with the vengeful, spiteful voice of the Neriani, the rival clan of devotees to the has-been diva Neri, who in their "anatema frenzy" (McCourt 1975, 27) spread rumour "a hurricane of 
to the collective voice is of crucial importance - the novel is about the relationship between the individual and the crowd. ${ }^{15}$ Only through such a relationship can one understand the notion of collective frenzy and the "libidinal commitment (musicry)" (McCourt 1975, 133).

If the diva's voice has a specific link to the collective, it is because she herself embodies it, incarnating multiplicity. She symbolizes the origin that the collective strives for. Indeed, at the centre of Czgowchwz's story there seems to lie one simple truth which demands revelation. With the devotees' indulging in a quest for such hidden truth, the revelation is supposed to be that of the original voice, the $u r$-voice. Indeed, the diva suffers a breakdown and plunges into amnesia. In order to recover her voice she uncovers her original, native tongue. She lies supine, supervised by a doctor called Zwischen, a name that means "between" in German but which to Slavic ears might suggest silence: cisza (Polish), ticho (Czech). The ur-voice stems from silence - symbolically, the revelation derives from the silent, dormant memory that is only uncovered by a shock, and the hypnotic digging into the diva's unconscious. The result is, tellingly, a doppelganger-diva, whose native tongue turns out to be Irish: "Ordered in trance to utter something in her own first language, she simply nodded, relieved, and commenced to go on and on again in Erse - describing to the bewildered Countess Madge explained, idyllic scenes of childhood and mumbling snatches of old ballads, canticles, keenings, and prayers [...]" (McCourt 1975, 114). The ur-voice is in fact latency, the latent memory of voices: "Whose voices are those back inside, chanting?" (McCourt 1975, 121) The latency of an original, true identity, which is in fact a latent multiplicity, since the diva's former self relates to both Irish-Gaelic and Slavic origins. She turns out to be "the love child of Ireland's Joan of Arc, Great Flaming Maev Cohalen, and the Czech philosopher-poet Jan Motivyk" (McCourt 1975, 127). Czgowchwz becomes a mythical figure "revealed as the orphaned love child of [...] Eire's own Boadicea, gone west into history [...]" (McCourt 1975, 130). Related to obvious traumas in Ireland, that of the Troubles, for instance, Czgowchwz is made to represent a primitive mythical voice, as though the recent past has been transformed into myth.

The revelation gives rise to a mythical aura around the figure of the diva, so that she becomes truth incarnate: "La vérité, c'est Czgowczwz?" (McCourt 1975, 155). And that truth is the reverse of voice: "Elle est maintenant le silence. C'est ça" (McCourt 1975, 156). The voice gives way to the fantasy of the first voice, the arkhé or the $u r$-voice, and the model form which everything stems, like a paradigm.

It could be argued that the voice serves as a fetish, as a projection of a lost multiplicity (or otherness). It seems clear that the voice is irrationally - and periodically - venerated. It seems obvious that it also metonymically connects to other symbolic notions such as identity, sexuality and gender. It becomes a fetish because it functions as part of an excessively adulated contiguous relationship. But then, the voice is collectively-invested. If the fetish is part-investment - the Freudian cathexis discussed in McCourt (2007) - it is collectively over-charged as part-hypostasis. And since the

gossip" (McCourt 1975, 175), slander and calumny. This is the violent performative voice representing a form of anti-vocality "spitting every vile hermetic Sicilian curse and oath" (McCourt 1975, 27) and "seditious obscenities" (McCourt 1975, 29). Such "black rosaries of blood curses" (McCourt 1975, 64) and "vitriolic testimony" (McCourt 1975, 65) present the reader with "the waspish arena of the opera." And there is also the community bardic voice: "The Bardic sidereal invocation, now keening, now exulting, swept on in melismatic quavers, vaulting thrusts, cadent torrents, spellbinding the warming assembly" (McCourt 1975, 58). And the collective voice of the crowd with its "shriek tendencies [...]" (McCourt 1975, 13) "singing a cacophonous mélange of favorite aria snatches” (McCourt 1975, 13).

15 The vocal paradox crystallizes with its unattainable distance and obvious proximity: "The Czgowchwz voice ('not projected, more infused - Percase) chartered immense distances at the one and the same time it invited intimate proximity, allowing revelation" (McCourt 1975, 154). 
oltrano is a crossover, it hints at gay culture. The insistence on opera fanaticism is closely related to the opera queen, understood as a gay subculture, especially through soprano fetishism. The use of the fourth-voice, the oltrano, seems to stand for the beyondness or the assumed otherness of gay culture. Moreover, the notion of incarnations and cross-gender impersonations ${ }^{16}$ that construct opera's theatricality and an effect of the carnivalesque ${ }^{17}$ contribute to the gender-ambiguity and an ambivalent eroticism of the fictional voice. Virtuosity itself is part and parcel of an eccentric embodiment of otherness, of that to which the self can never gain access. The fetishistic drive behind the libidinal investment of the voice seems to lay bare fantasies of inaccessible otherness. Czgowchwz's voice is clearly a multiple voice of multiple impersonations. The oltrano is not only the other voice, the new voice, but it is also the voice of the other, originating form a hypertrophied assimilation of otherness.

The diva embodies ambivalence and incarnates androgyny, having several voice ranges, having sung in forty roles and played double roles, such as Aneas and "Dido, in the same opera (in the same performance)" (McCourt 1975, 6). The two major impersonations, Isolde in Tristan \& Isolde, and Mélisande in Péléas \& Mélisande are based on the sexual ambiguity to which the text refers:

[...] two young boatswains, each of whom the diva recalled as a perfect example of the astonishing open beauty the Irish possess, undifferentiated by gender - the men and the women matching feature top feature, seemingly all compact of variant qualities in the single angelic order of androgyny." (McCourt 1975, 102)

The gender ambiguity is heightened by the coupling of the diva with a countertenor, Jacob Beltane. Alluding to Celtic summer rituals, predicated on the fire element, ${ }^{18}$ Beltane is the literalisation of Czgowchwz's otherness, her androgynous second half. The mirror effect occurs when the countertenor realizes he himself is an oltrano. ${ }^{19}$ The voice becomes the nexus of the feminine/masculine fusion. "That shy, lovely, tall, angelic, feral boy" (McCourt 1975, 158) can only remind us of the feminine impersonations in opera by men, and especially the castratti. ${ }^{20}$ As the diva, Beltane embodies a vocal archetype: "[...] there is a boy possessed of a voice of elfin majesty. [...] The voice! The voice" (McCourt 1975, 167). The parallel seems obvious: "Oltrano faced oltrano: singing woman/singing man" (McCourt 1975, 169).

16 The practice of travesty and impersonation is clearly embedded within the narrative, and does not necessarily relate to the diva. The carnavalesque is one such example of collective impersonations and voice-use, what with street plays or mummers, celebrating the winter solstice through the ritual, totems, and orphic rites to which the novel refers. Moreover, the characters take part in a game called "attitude charade", parodying opera scenes, gestures and performances, "[...] sketching a kind of mimetic précis that was soon discovered to be the emblem of a certain role as characteristically performed by a certain major artist or comprimario star" (McCourt 1975, 61). This impersonation displays the playful trick played by the initiates, a game of travesty and pastiche that is both hilarious and violent. The diva and the voice are celebrated through such mimicry which constitutes a deforming mirror to performance where one can catch a glimpse of libidinally invested travesty.

17 The novel clearly displays the carnavalesque in opera, with characters partying in operatic masquerade and travesty: "the Countess Madge as Norma, Ralph as Falstaff; Alice as mad Maneris, Carmen as Black Swan Odilke; Dixie as Fafner ..." (McCourt 1975, 200). One can hardly help thinking about gay pride aesthetics mingling with the parodic reprise of Wagner's gods: "Perched at the top of a gigantic rainbow Ferris wheel while throngs below danced and sang, ate and drank, won and lost cash, laughed and cried, Mawrdew Czgowczwz and Jacob Beltane, like twin aerial monarchs, looked down upon creation" (McCourt 1975, 201).

18 ten means fire in ancient Irish.

19 "While listening to the Pelléas et Mélisande, silently singing both roles, Jacob Beltane came to the realization: 'I am a true oltrano as well.'” (McCourt 1975, 155).

20 The gender issue is alluded to - the public seems to have doubts as to Beltane's masculinity: "how does he make his noise? [...] I hear most of the audience spent most of the evening looking - speculatively - at the creature's crotch!" (McCourt 1975, 171), which alludes to debates about eunuchs' sexual potency that surrounded the castrati. 
Ambiguity arises from the union of the two singers, as gender issues connote a specific form of eroticism: "The new oltrano drank in the speaking voice of the woman he felt he now possessed - as her singing voice had possessed him - and laughed the laugh of pure submission. Possession/ submission simultaneously informed oltrano and oltrano" (McCourt 1975, 175). The sexuality of the voice seems even more ambiguous than questions of gender. ${ }^{21}$ While the two singers interpret the role of twin brother and sister in the fictitious opera Noia, their voices incestuously interrelate, converging within the same whistle register:

The voices of Czgowczwz and Beltane made tender, sinuous, bold, and delicious love, singing one over another, suddenly under, then tumbling over and under, then ultimately converging on some same single notes - resonating, vibrating, arching, plummeting.

\section{(McCourt 1975, 189)}

The specificity of the voice-fetish here lies in its hovering between its own impossibility - its annihilation within silence - and its universality, the multiple pan-sexual, genderless otherness. But, perhaps, fetishism is all about annihilation of centrality, indeed. A voice totem - fetish per excellence - is created for the ancient diva "a totem of Neri dressed in fragments of costumes meant to represent her several starring roles" (McCourt 1975, 63), but it melts away faced with the fiery sun of the oltrano.

\section{Conclusion}

McCourt's novel is not just about any idolatry, it is about "Mawrdolatry" (McCourt 1975, 3), a fetishist adulation of a diva's fantastic voice. It is not just about any music but about "musicry" (McCourt 1975, 4), that is the hypertrophic travesty - the mimicry - which the diva incarnates. The voice is at once android and androgynous. The novel presents us with a fabulous, burlesque, carnavalesque, comic and parodic world of the New York opera, interrogating the extremes of operaphilia. The hysterical devotion constitutes the caricature of a grotesque mode of adulation. But by telling us the story of self-sufficiency and histrionics, the novel also questions vocal identity. The voice is elusive, so that none of the terms - "magody, lysody, hilarody, simody, travesty, mimicry" (McCourt 1975, 15) - can be used to pin it down. Identity, too, seems ungraspable. Hence, the representation of the impossible oltrano voice capable of "humming one of the Ondes Martenot lines in Messiaen's Turnagalila" (McCourt 1975, 42) tells us something about otherness by questioning gender categories and interrogating the fantasies the voice may be vested in. "Diva" clearly chimes with divine ${ }^{22}$ and is clearly at one with myths of origins. The oltrano reminds one of fantasies of an $u r$-voice or a vocal archetype. And the story of the oltrano is also that of a fantasized word and music communion, achieved by means of an eccentric fabulous extension of the voice that arrives at "that rarest effect, the wedding of word to music, the contoured interlock of syllable and sound" (McCourt 1975, 190). The novel itself alludes to its own musico-literary miscegenation, by speaking about "dancing figures in the words"

21 The finale of the opera turns out to be predicated on agonistic tension that digs into gender and sexual unconscious: "The family romance, the ageless conflict of unconscious archetypes, incest taboos branded upon all human intercourse, the crises of identity and self-encounter interweave thematically to precipitate a mangled denouement" (McCourt 1975, 193). The communion may be interpreted as male identification with the female destruction/submission in opera by the male, as it may be understood as a self-gendered self-sufficiency: "oltrano for oltrano".

22 But the New York diva saga seems to be doomed to undergo the fate of Wagner's gods in Götterdämmerung as the cyclical temporality and the paronomastic pun on New York's other name, Gotham, seems to suggest. The fall of the diva seems clearer 40 years on with the publication of Now Voyagers, where the singer, reconverted into a psychoanalyst, decides to trace back her origins by returning to her native Ireland. 
providing a list of effects of which words are capable. Among the possible categories, the fifth category belongs to "the words in a pattern of intentional sounds, aspiring to the condition of music" (McCourt 1975, 205). Hence, the text points indirectly to the very interrelations between music and literature.

\section{References}

Bernhart, Walter, ed. 2006. Word and Music Studies. Selected Essays on Opera by Ulrich Weisstein. Amsterdam: Rodopi.

Brown, Calvin S. 1987. Music and Literature: A Comparison of the Arts. Hanover: UP of New England.

Cupers, Jean-Louis, and Ulrich Weisstein. 2000. Word and Music Studies. Musico-Poetics in Perspective: Calvin S. Brown in Memoriam. Amsterdam: Rodopi.

Dolar, Mladen. 2006. A Voice and Nothing More. Cambridge, MA: The MIT Press.

Halliwell, Michael. 2005. Word and Music Studies. Opera and the Novel: The Case of Henry James. Amsterdam: Rodopi.

Le Breton, David. 2011. Éclats de voix: une anthropologie des voix. Paris: Métaillé, Traversées.

Louvel, Liliane. 2011. Poetics of the Iconotext. Farnham: Ashgate.

McCourt, James. 1975. Mawrdew Czgowchwz. New York: New York Review Books.

-. 2007. Now Voyagers: The Night Journey. Some Divisions of the Saga of Mawrdew Czgowchwz, Oltrano. Authenticated by Persons Represented Therein. Book One. New York: Turtle Point Press.

Sacido-Romero, Jorge, and Sylvia Mieszkowski, eds. 2015. Sound Effects: The Object Voice in Fiction. DQR Studies in Literature, Vol. 59. Leiden: Brill, Rodopi.

Scher, Steven P. 1982. "Literature and Music.” In Interrelations of Literature, edited by Jean-Pierre Barricelli and Joseph Gibaldi, 225-50. New York: The Modern Language Association of America.

Stawiarski, Marcin. 2015a. "L'intermédialité musico-littéraire et la notion d'excentricité." In Littérature médiagénique: Écriture, musique et arts visuels. Logiques Sociales, edited by François Guiyoba, 15-50. Paris: L'Harmattan.

—. 2015b. "Existe-t-il des métaphores musicales en littérature?" In Métaphore et musique. Interférences., edited by Inès Taillandier-Guittard, 127-48. Rennes: Presses Universitaires de Rennes.

Wesling Donald, and Tadeusz Sławek. 1995. Literary Voice: The Calling of Jonah. New York: State University of New York Press.

Wolf, Werner. 1999. The Musicalization of Fiction: A Study in the Theory and History of Intermediality. Amsterdam: Rodopi. 